\title{
Reading Circles With Sherlock Holmes Graded Readers
}

\section{Christopher Robert Cooper \\ Rikkyo University}

\section{Reference Data:}

Cooper, C. R. (2020). Reading circles with Sherlock Holmes graded readers. In P. Clements, A. Krause, \& R. Gentry (Eds.), Teacher efficacy, learner agency. Tokyo: JALT. https://doi.org/10.37546/JALTPCP2019-52

One elective class of 6 students at a small private university in Japan read Sherlock Holmes graded readers for one semester in a reading circle class. Reading circles involve students reading books readers for one semester in a reading circle class. Reading circles involve students reading books
and having discussions with a specific role, such as the Discussion Leader, Passage Person, Word Master, Summarizer, or Connector. These reading circle roles are explained using examples from students' written notes, which were made to help them with the discussions. This provides a representation of the kind of oral output instructors may expect if they decide to try reading circles in their classrooms. Comments from the instructor's reflective log and student surveys are reported to give greater insight into how future reading circle courses could be implemented. It was concluded that this activity may be useful to encourage interest in $L 2$ reading at institutions with no extensive reading program.

リーデイングサークルクラスを選択した日本の大学生 6 人が、一学期に渡以、英語多読本「シャーロックホームズ」の読書に 取り組んだっリーデイングサークルレは、ただ単にグループで本を読むだけでなく、Discussion Leader, Passage Person, Word Master, Summarizer, Connectorなどの役割分担を各メンバーに持たせ、会話や討論を綵り広げることであるってれらのリーデ イングサークルの役割については学生が書いたメモの例を用いて説明するが、このメモは、討論の際に役立つように、学生 に書かせたものである。されは、リーデイングサークルを授業で䒠施する場合に、教師が期待するであろう学生の口頭の発言

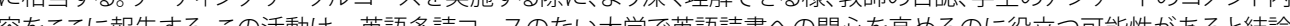

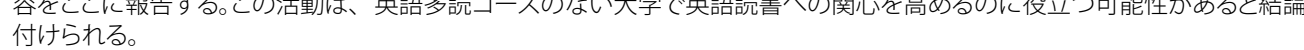

xtensive reading involves learners silently and comfortably reading a large amount

of comprehensible reading material at their own level and speed; ideally hundreds of thousands of words should be read per year (Nation \& Waring, 2019). Large word counts can be daunting for some students who may be time starved and not used to reading English books. To introduce extensive reading, The Extensive Reading Foundation suggest beginning with whole class reading in the early stages to focus on the enjoyment of easy reading compared to the often difficult material provided in textbooks (2011). In the current study, the researcher extended this idea over one semester and conducted action research to evaluate reading circles as a potential way to encourage reading for pleasure whilst avoiding large amounts of required reading in a university with no extensive reading program.

\section{EFL Reading Circles}

Reading circles, also known as literature circles, have been frequently used in elementary and high schools in the United States since the 1980s (Daniels, 2002). They are similar to adult book groups, where students meet regularly to discuss a book, with the difference being that each group member has a specific role to fulfil.

In the last 10 to 15 years, several researchers have investigated the benefits of using reading circles in EFL contexts. Some of the perceived benefits reported by 15- to 17year old Vietnamese learners of English in Shelton-Strong's (2012) report included increased reading speed, increased ability to guess the meaning of new words, and feeling more comfortable speaking English. In a Japanese high school, LeBlanc (2015) found a statistically significant increase in her participants' $(N=316)$ reported reading self-efficacy and a decrease in reported reading anxiety. In a Japanese university context, after taking part in reading circles for one semester, Mark's (2007) students $(N=134)$ reported on a 5 -point Likert scale that reading circle discussions helped them understand the content of their books $(M=4.25, S D=0.96)$ and appreciate graded readers $(\mathrm{M}=4.33, S D=0.89)$. 
In the EFL classroom, Furr (2011) suggested that instructors should use the following guidelines for reading circles:

- Suitable reading material selected by the teacher;

- Students form small, temporary groups;

- The same text is read by the whole class;

- A regular, predictable schedule to discuss reading;

- Students' written notes are used to guide reading and discussion;

- Students decide the discussion topics;

- Open, natural discussion about stories;

- The teacher's role is facilitator, not instructor or group member;

- There is a fun, playful atmosphere in the room.

The following six roles are suggested for use with EFL learners: Discussion Leader, Summarizer, Connector, Word Master, Passage Person and Culture Collector (Furr, 2011). The Discussion Leader controls the reading circle by asking questions, calling on students, and ensuring everyone is participating. The Summarizer writes and shares a short summary of the week's reading, including main events and character points. The job of the Connector is to share an experience that is connected to the story. This could be one of their own, someone they know, or a real-life event, such as a news story. The Word Master chooses five words that are important to the story and explains their meaning. The Passage Person finds key passages that are interesting or important in some way, explains why they chose the passages, and asks questions about them. Finally, the Culture Collector finds passages that show cultural differences and similarities and asks questions about them. Furr (2011) suggested that the Culture Collector is the most challenging role and should be introduced after learners have read at least one story in a reading circle; therefore, it was not used in this study.

\section{Action Research Study}

\section{Participants}

One class of six 2nd- and 3rd-year students who were enrolled in an elective topic study class in the College of Humanities and Social Sciences at a small private university in the Kansai region of Japan took part in the study. The students' reported level ranged from beginner to intermediate, and their self-reported TOEIC and Eiken scores indicated a
CEFR level of A1-A2. All the participants gave informed consent to participate in the study and the research guidelines of the university were followed.

\section{Materials}

The Oxford Bookworms graded reader series was chosen because free resources were available online from Furr's (2011) handbook, including role sheets. The worksheets aid students when preparing for discussions by breaking down each role into steps, providing questions for the students to answer, and giving model passages for each role. Sherlock Holmes books were chosen to encourage narrow reading (Renandya, Krashen, \& Jacobs, 2018), which entails reading several books by the same author, in the same series, or within a specific topic area that the reader is interested in. Doing narrow reading may make books more comprehensible due to the reoccurrence of vocabulary, familiar story lines, and characters that become more relatable.

As this was an elective course, the actual level of the students was unknown when the curriculum was designed, so lower level books were chosen to try to accommodate all students, but choosing the appropriate level was difficult. Sherlock Holmes was chosen as several books were available at Stages 1 and 2 of the Oxford Bookworms Library. To allow for comparison with other graded reader series, Oxford Bookworms readers have a yomiyasusa [reading ease] level (see Furukawa, 2014) of 2.0-2.4 for Stage 1 and 2.62.8 for Stage 2. In the period of the current study, the students read the Stage 1 books Sherlock Holmes and the Duke's Son (Conan Doyle, 1998), containing seven chapters and 5,800 words, and Sherlock Holmes and the Sport of Kings (Conan Doyle, 2003), containing six chapters and 5,925 words. Students who continued with the course in the semester following the current study read the Stage 2 books Sherlock Holmes: Short Stories (Conan Doyle, 1989) and Sherlock Holmes: More Short Stories (Conan Doyle, 2018).

\section{Procedures}

The class met for 90 minutes once a week for one semester. The syllabus was structured around reading and discussing the Sherlock Holmes graded readers. One or two chapters were read each week and all compulsory reading, preparation, and the discussion were done in class. Students were also encouraged to read the week's chapter before and/or after class to aid their comprehension. Generally, a class included

1. 15 to 20 minutes of sustained silent reading,

2. 30 minutes of discussion preparation, and

3. 30 minutes of discussion. 
The remaining time was spent doing other activities. The students were allowed to choose which role to fulfil, with the aim of making them feel comfortable joining the discussion in this mixed ability class, as some roles are more challenging than others.

During the 15-week spring semester of 2019, the students' role sheets were collected, and the data taken from them were analysed to represent the students' output during the reading circle classes. Whilst this does not fully represent the discussions that took place, it is a fairly accurate account of the type of student output that occurred in this class. Several weeks of data are missing due to assessment weeks, weeks when students were assigned reading for homework. and weeks when all of the reading circle roles were not filled due to student absences.

The researcher completed a reflective log immediately after each class. Reflections were recorded under categories such as student roles, warm-up activities, the discussion, and changes to make in the following class. The students completed mid-term (Appendix A) and end-of-term (Appendix B) surveys to allow the instructor to gain insights from the students that could not be gained from observation.

\section{Results and Discussion}

\section{Discussion Leader}

The main role of the Discussion Leader is to ask questions about the story. The students were given little guidance about what kind of questions to ask, but they were shown model questions from the reading circle role sheets.

The questions students asked in the reading circle were organised into categories during data analysis to gain an understanding of the types of question they naturally asked. The question types were taken from Day and Park (2005) who classified comprehension questions into six categories to support instructors who write postreading questions. The participants in the current study were not aware of these question types, and they were used for analysis only. The examples in the following paragraph were questions asked in this study.

The first question type is literal: The answer to the question is explicitly stated in the text, for example, "What is in John Straker's pockets?" The second type is reorganization: The answer is not explicitly stated, but the reader needs to put several pieces of information together from different sections of a passage. An example is "How many horses did Silver Blaze overtake?" in which the reader gathers the racehorse Silver Blaze's starting position and final position from the text to answer the question. The third question type is inference: The reader uses information they know about the characters and previous events to infer an answer to the question, for example, "Why (did) $\mathrm{Mr}$ Ross look Silver Blaze up and down?" The fourth question type is prediction: The reader infers something that may happen later in the text, such as "Who do you think killed Heidegger?" The fifth question type is evaluation. No examples were observed in this study, but here is an example: "What useful English could you use from this chapter?" The final question type is personal response: The reader inhabits the thoughts of the character, for example, "If your son or daughter (was missing) what would you do?" The frequency of each question type recorded in the study is shown in Figure 1.

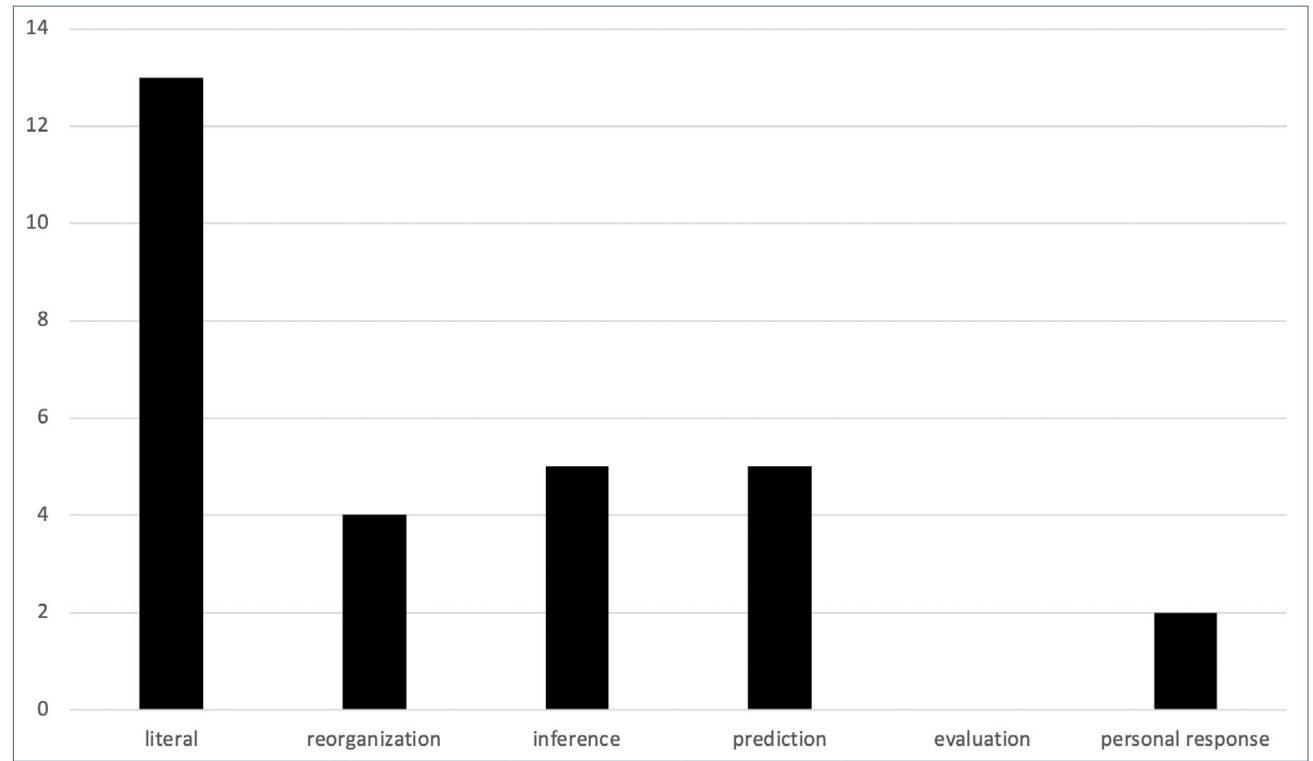

Figure 1. Discussion leader question types.

The most frequent question type was literal. In the reflective journal, the researcher commented that literal questions seemed to be the easiest to answer; other question types were often followed by long pauses. The students may have been aware of this and purposefully asked questions that were easier for their classmates to answer to improve the flow of the conversation. Despite this, a range of different question types were asked, with the exception of evaluation. This type of question is not about events in the story, which may be the reason learners did not ask it. 


\section{Passage Person}

The role of the Passage Person is to find important, interesting, or surprising passages in the text, explain why they chose the passage, and ask questions about it. Table 1 is an example from the current study.

\section{Table 1. Passage Person Example}

\begin{tabular}{lll}
\hline Passage & Reason for choosing & Question \\
\hline "Er, no," I said, "One tyre & I think it is important and & Why do you think the rear \\
makes a deeper track." & informative & wheel of the tyre (track) is \\
"And that's the back wheel," & & deep? \\
said Holmes. & &
\end{tabular}

The same six comprehension types were used to analyse the frequency of question types for the Passage Person students. The above example question was literal, as the answer was explicitly stated in the text. The frequency of other question types is shown in Figure 2.

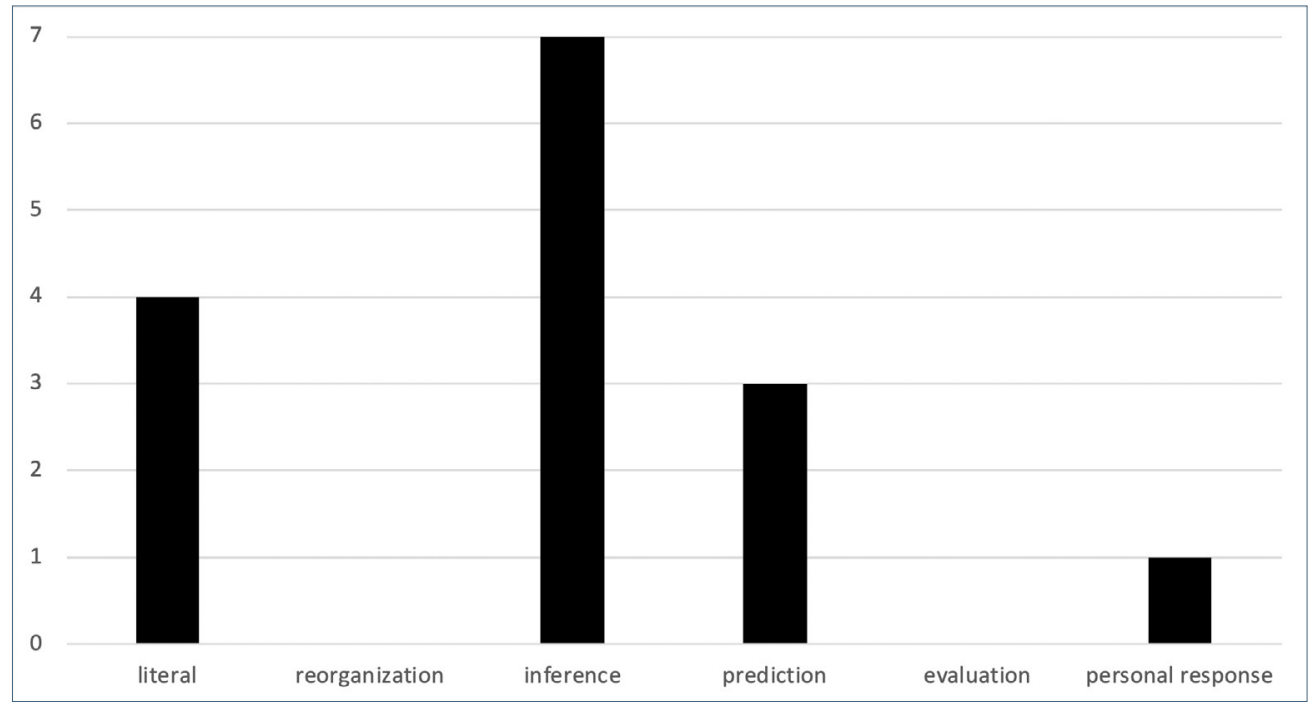

The most frequent question type was inference. The types of question asked were slightly different when compared to those of the Discussion Leader. This could be due to the nature of the role, as the Passage Person asks a question about one specific small portion of the text, which could make more challenging questions such as inference questions more answerable.

\section{Word Master}

The Word Master's role is to find five words in the text that are important to the story. They share the words with the group, explain the meaning using their L1 or L2, and state their reason for choosing the word. The reasons from this study are shown in Figure 3.

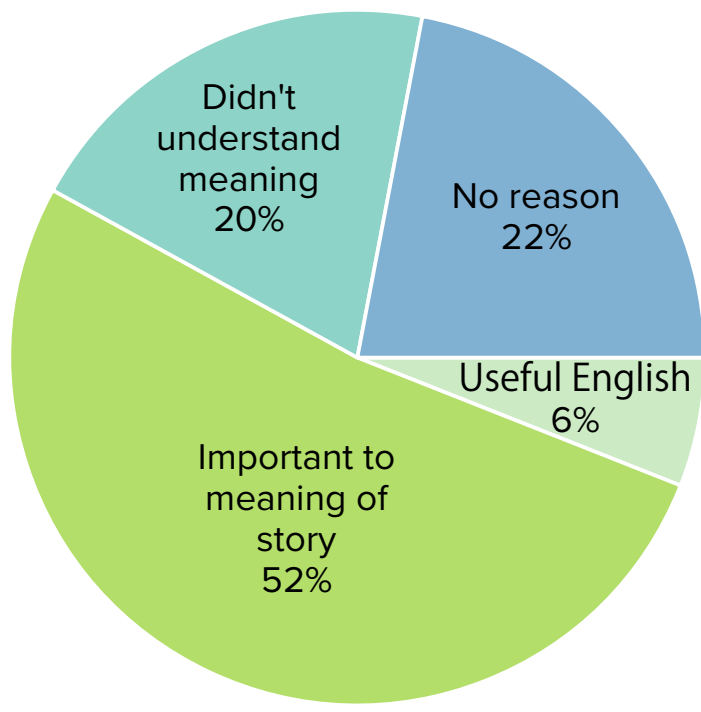

Figure 3. Reasons for choosing vocabulary.

The most frequent reason, important to the meaning of the story, was perhaps a little vague. On reflection, the students could have been encouraged to give more specific reasons, for example, how is it important to the meaning, or they could have been asked to search for words that are repeated often or used unusually. In the poststudy survey, all six participants reported that this was the easiest role.

Figure 2. Passage person question types. 
The chosen words were analysed using LexTutor (Cobb, 2019) to understand the types of vocabulary the learners chose. The learners' vocabulary list was compared with the New General Service List (NGSL; Browne, Culligan, \& Phillips, 2013b) and the New Academic Word List (NAWL; Browne, Culligan. \& Phillips, 2013a), which are lists of core high-frequency vocabulary designed to help learners of English as a second language. They were chosen because the participants of the current study had studied them in other classes. The results of the analysis are shown in Figure 4.

\begin{tabular}{|c|c|c|c|c|}
\hline & & & & tendon \\
\hline win & & & & racehorse \\
\hline white & & & & racecourse \\
\hline up & & & & opium \\
\hline tracks & & & & mud \\
\hline possible & & & & midday \\
\hline poor & & & & lame \\
\hline police & & & & killer \\
\hline perhaps & surely & & & ivy \\
\hline move & owner & & & inspector \\
\hline moment & murder & & & inn \\
\hline laugh & minister & & & horseshoe \\
\hline large & map & & & footprints \\
\hline killing & horse & servant & & duke \\
\hline kept & hill & quietly & & dishonest \\
\hline government & disappears & mystery & & detective \\
\hline dress & disappeared & maker & & cheque \\
\hline bill & betting & envelope & & bark \\
\hline NGSL 1 & NGSL 2 & NGSL 3 & NAWL & Off List \\
\hline 1000 & 1000 & 801 & 963 & \\
\hline
\end{tabular}

Figure 4. LexTutor analysis of Word Master vocabulary.
Of the words chosen that appear in the NGSL, higher frequency vocabulary items appeared the most. No words were selected from the NAWL. This could be due to the low level of the learners, or it could be because of the controlled vocabulary of the lowlevel graded readers used in the study. Most chosen words were off list, meaning they were low frequency words. Of these words, several could be useful for reading Sherlock Holmes or other detective books such as killer, inspector, detective, or footprints. Several other vocabulary items could be useful for reading books written in a similar period of history such as cheque, horseshoe, inn, or opium. These words were most likely chosen because the students came into contact with them for the first time.

\section{Summarizer}

The Summarizer makes notes about the main events and characters in the chapter and writes a short summary paragraph. Here is a typical example from this study:

Very early this morning. They went to the park and found a track (sheep and cow), but no bicycle tracks. Found the back of a bicycle near the river, but different tyres, and Holmes kept searching and found Heidegger after 2 hours. Heidegger dead! No footprint. No track, only cow's footprint.

It was commented in the research journal that this role was the least communicative. Sometimes summaries were missing key details, which gave other group members the opportunity to add to the summary, but usually this was not the case. As shown in Figure 5 , the number of words written was fairly low. Although this could indicate that the summaries were well written, the Summarizer seemed to be a challenging role for this class. 


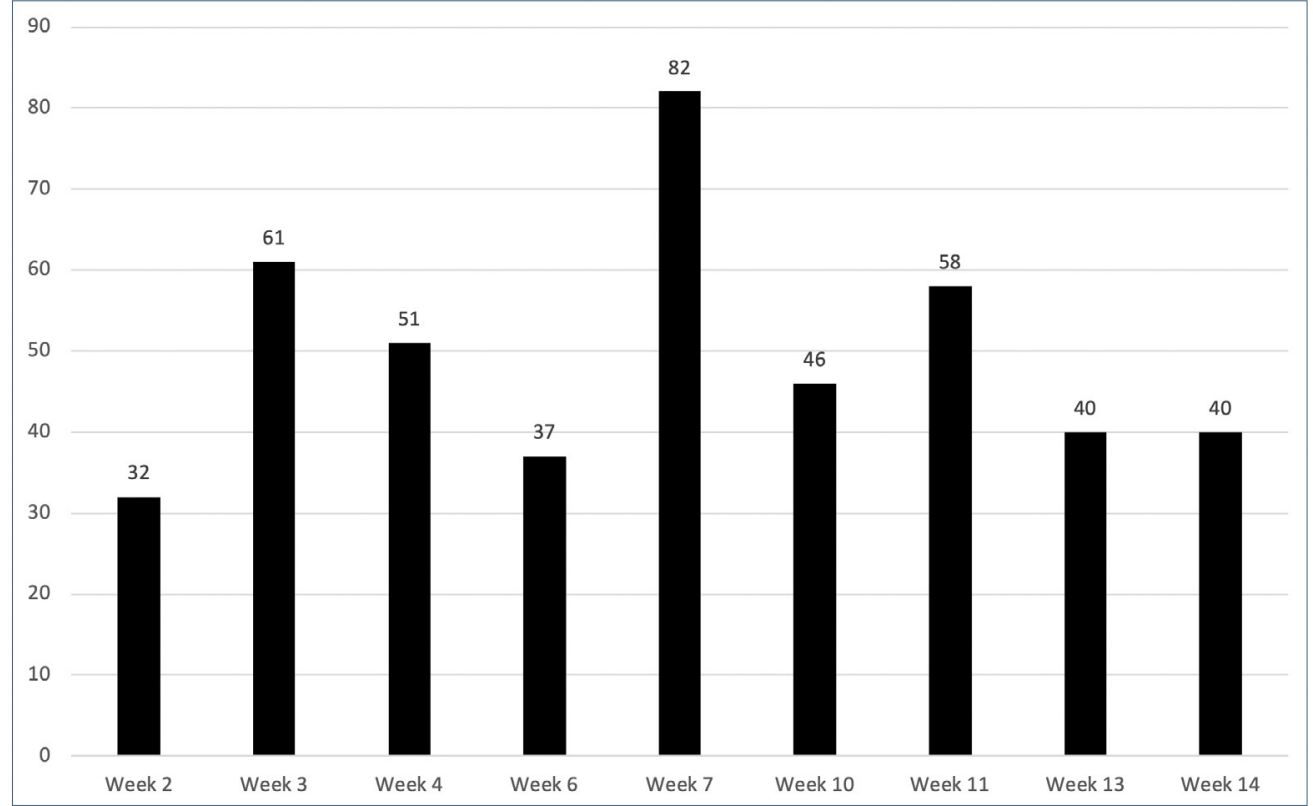

Figure 5. Number of words written by the Summarizer.

\section{Connector}

The Connector's job is to link something from the story with an experience from their own life, the life of someone they know, or another event such as a news story. Here is a typical example of a connector story from this study:

I was mistaken for breaking the water tank. When I was in elementary school. The water tank was broken when I went to school the next day. Then the teacher came and asked everyone in the class why it was broken. Everyone was saying that I did, but l'm not doing. As a result of discussion my friend was the criminal. Everyone was saying without evidence.

In the Sherlock Holmes story, a character was wrongly accused of murder, which inspired this connection to a false accusation in the lower-stakes scenario of a broken fish tank. In the poststudy survey, four out of six students reported this role to be the most interesting. The role encourages creativity and personal responses to the story, prompting interesting discussions about past experiences. A summary of the connections made by all of the Connectors in this study is shown in Table 2 .

Table 2. Summary of Connector Story Topics

\begin{tabular}{ll}
\hline \multicolumn{1}{c}{ The Duke's Son } & \multicolumn{1}{c}{ The Sport of Kings } \\
\hline Stolen Vegetables (possibly by a mouse) & Friend's big win at horse racing \\
School was similar to school in story & Wrongly accused (broken fish tank) \\
Bicycle tracks in garden (her dad's) & Overdue bill \\
Missing club room key & Always losing the race at sports day \\
Bumping into an old school friend & Caring for an injured sparrow \\
\hline
\end{tabular}

Several of the Connector stories were mystery related, in which things were missing or stolen, which are common themes in Sherlock Holmes stories. When reading The Sport of Kings, one connection was related to gambling on horse racing and one to losing at a school sports day race. These examples were specific to themes in the graded reader. Other examples related to small, specific events in the Sherlock Holmes books, such as an overdue bill which was found in one of the characters' pockets, which prompted a story about an unpaid credit card bill found in one student's bedroom when they were cleaning. The range of story topics and justifications for linking them to the Sherlock Holmes story was interesting.

It seemed to take a couple of weeks for students to become familiar with the Connector role. As is shown in Figure 6, after Week 2, the number of words written in the early weeks was very low. As students heard Connector examples given by their classmates, what was expected of this role probably became clearer, and the students were able to contribute longer stories. 


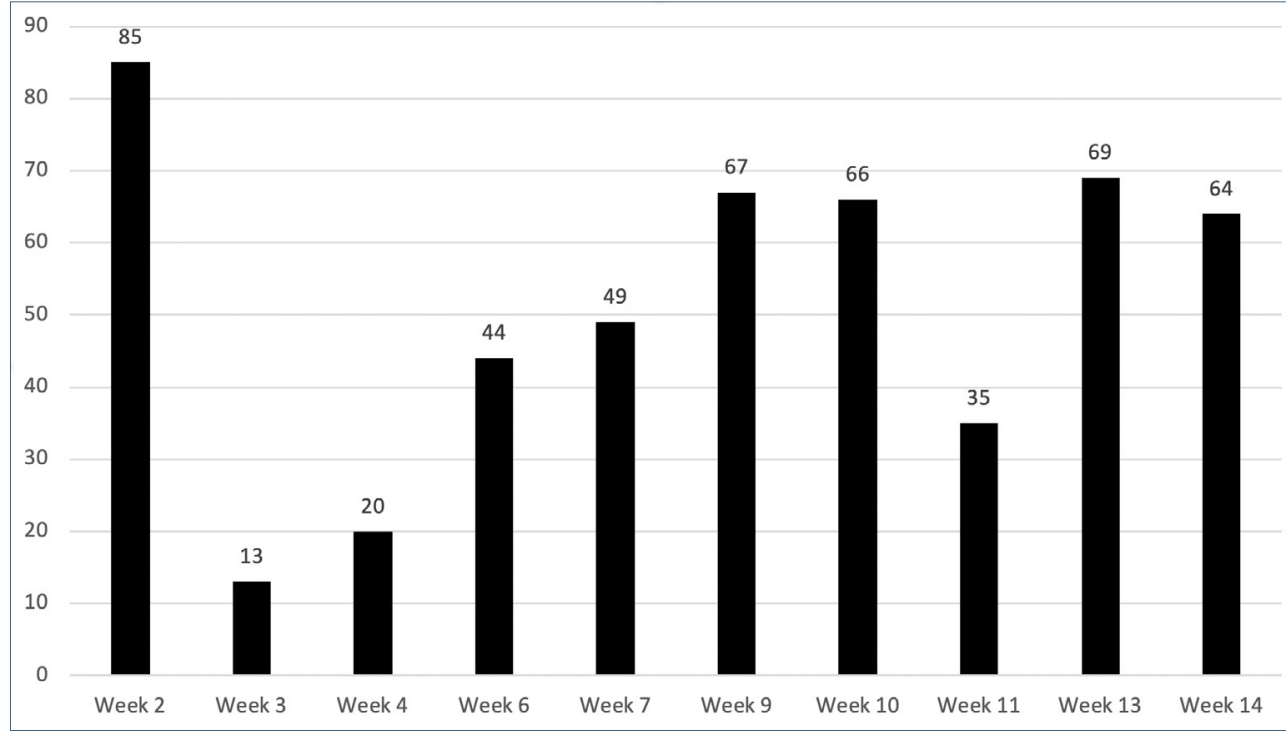

Figure 6. Number of words written by the Connector.

\section{Additional Reflective Log Observations}

At the beginning of the semester, extra warm-up activities in the class, such as puzzles and video clip activities, were related to Sherlock Holmes but not to the story. Due to concerns that some students may not have been fully comprehending the story, these activities were replaced by a teacher-led review of the previous week's story, including showing and talking about pictures of characters and drawing maps. Towards the end of the semester, students were given schema-building activities, such as a map containing the main places of the story and time to use the Internet to find pictures and information about the places.

It was noted that the role sheet preparation was generally good, but the discussions rarely deviated from students reading their role sheets. Various techniques were tried to encourage natural communication. The one that seemed to be the most effective was allowing students to speak in pairs before the group discussion, allowing for practice, repetition, and the chance to make mistakes in front of a smaller audience. In a larger class, students doing the same role could discuss their ideas together before returning to their original group for the reading circle.
At the beginning of the semester, the guideline of the teacher's role as a facilitator and observer rather than a group member or instructor was strictly followed. However, as the semester progressed, due to comments in the reflective log, the teacher decided to support the students more. This support included conferencing with individual students during role sheet preparation, asking extra questions during the reading circle, and acting as a second summarizer at the end of the discussion to aid comprehension.

\section{Mid-Term and End-of Term Survey Results}

Due to space constraints, only some of the survey results are reported here; the full results are available in the PowerPoint slides used in the original conference presentation (Cooper, 2019).

In the mid-term survey, the students reported what they could do to understand the story and join in the discussion more. Their suggestions included reading the story before and after class, looking at the glossary in the book, and not being shy. They were also asked what the teacher could do to aid comprehension and encourage participation in the discussion. Their ideas included the teacher drawing pictures on the white board about the story and characters and talking loosely about the story after the group discussion. Both comments matched observations made in the reflective log and were put into action in the second half of the semester.

In the end-of-term survey, to try to understand if the students were interested in reading English books for pleasure, they were asked the questions shown in Table 4 and Table 5. Higher scores in the 5-point Likert-scale items indicate positive responses.

Table 4. Interest in Reading More Sherlock Holmes Books in English $(N=6)$ R

\begin{tabular}{cl} 
Rating & Comment \\
\hline 5 & I want to read another mystery story. \\
4 & Because I like mystery. \\
4 & I have never read Sherlock Holmes books in English. \\
3 & $\begin{array}{l}\text { This book's criminals are surprising person, so I thought it was interesting. } \\
3\end{array}$ \\
I'm interested in Sherlock Holmes because I like Detective Conan. But l'm not \\
good at English. \\
I don't like mystery story. It's too difficult. \\
Note. $1=$ low / 5 = high. \\
GE
\end{tabular}


Table 5. Interest in Reading Other English Books $(N=6)$

Rating Comment

5 I want to read different genre from Sherlock Holmes.

$4 \quad$ I would like to read other books.

$4 \quad$ I thought English books are different than Japanese books and I can acquire English skill.

3 Because I do not read English books.

3 No comment.

2 Because I cannot read and understand English. I cannot understand.

Note. $1=$ low $/ 5$ = high.

Students giving higher ratings enjoyed the mystery genre and had an interest in reading more English books. The students giving lower ratings seemed to have comprehension difficulties with the English language and the genre of mystery.

\section{Conclusion and Future Suggestions}

Based on the data and the reflections of the researcher recorded in the reflective log, there seemed to be several pros and cons of using reading circles with this group of learners. On the positive side, the output generated by the students was meaningful, as it was related to the stories and the students were connecting the reading to their individual lives and experiences. The regular, familiar format of the reading circle seemed to aid the students' output, after the steep learning curve of the initial weeks. Another benefit of this approach is that it allows students to practice four skills by reading the book, writing notes to facilitate the discussion, and listening and speaking during the weekly discussions.

One reading circle guideline that was not met in this study was open, natural conversation. The participants heavily relied on their written notes and rarely deviated from them in the discussion. There were often long pauses after questions were asked and some of the questions were not answered at all. This may be unavoidable in an L2 reading circle involving students of this level, or it could have been due to the level of the books. As the books needed to be chosen before students had registered for the course, it was difficult to match the books to the students' level. There were not enough graded readers in the library to provide a copy for each student. However, another option may have been to use an online graded reader service, such as Xreading (xreading.com) This would allow the learners to find their reading level, even if this involved reading shorter books and possibly reading a new book every week. That said, if learners choose their own books, they may not do narrow reading, which was one of the goals of this interpretation of reading circles.

Hopefully, this paper has provided an accurate account of how reading circles were used in one small EFL classroom at the university level in Japan. This activity could be useful in courses at institutions that do not have extensive reading programs or where students are not accustomed to reading a large amount in their L2. Reading circles encourage creative and interesting output and can be a useful step in the L2 reading journeys of learners in Japan.

\section{Acknowledgments}

I would like to thank all of the participants in the study for their cooperation and Yuriko Cooper for translation support.

\section{Bio Data}

Chris Cooper has been teaching English in Japan since 2010 and currently works at Rikkyo University in Tokyo. He holds an MA in TESOL from Sheffield Hallam University. His research interests include extensive reading, extensive listening, task-based language teaching, and corpus linguistics. <cooperchris17@gmail.com>

\section{References}

Browne, C., Culligan, B., \& Phillips, J. (2013a). The new academic word list. Retrieved from http:// www.newgeneralservicelist.org

Browne, C., Culligan, B., \& Phillips, J. (2013b). The new general service list. Retrieved from http:// www.newgeneralservicelist.org

Cobb, T. Compleat Web VP v.2.1 [computer program]. Retrieved from https://www.lextutor.ca/vp/ comp/

Conan Doyle, A. (1989). Sherlock Holmes: Short stories. Oxford, England: Oxford University Press.

Conan Doyle, A. (1998). Sherlock Holmes and the Duke's son. Oxford, England: Oxford University Press.

Conan Doyle, A. (2003). Sherlock Holmes and the sport of kings. Oxford, England: Oxford University Press. 
Conan Doyle, A. (2018). Sherlock Holmes: More short stories. Oxford, England: Oxford University Press.

Cooper, C., R. (2019). Reading circles with graded readers [PowerPoint slides]. ResearchGate. https:// doi.org/10.13140/RG.2.2.29236.19842

Daniels, H. (2002). Literature circles: Voice and choice in book clubs and reading groups. Portland, OR: Stenhouse.

Day, R. R., \& Park, J. S. (2005). Developing reading comprehension questions. Reading in a foreign language, 17(1), 60-73. Retrieved from https://nflrc.hawaii.edu/rfl/April2005/day/day.html

The Extensive Reading Foundation. (2011). The Extensive Reading Foundation's guide to extensive reading. Retrieved from http://erfoundation.org/guide/ERF_Guide.pdf

Furr, M. (Ed.). (2011). Bookworms club reading circles: Teacher's handbook. Oxford, England: Oxford University Press. Retrieved from https://elt.oup.com/teachers/readingcircles/?cc=jp\&selLanguag $\mathrm{e}=\mathrm{ja}$

Furukawa, A. (2014). Yomiyasusa levels, reading levels for Japanese students. Retrieved from https:// www.seg.co.jp/sss/YL/What_is_YL.html

LeBlanc, C. (2015). Investigating high school students' self-efficacy in reading circles. The Language Teacher, 39(1), 15-21. https://doi.org/10.37546/JALTTLT39.1-3

Mark, P. L. (2007). Building a community of EFL readers: Setting up Literature Circles in a Japanese university. In K. Bradford-Watts (Ed.), JALT2006 Conference Proceedings (pp. 998-1012). Tokyo: JALT. Retrieved from https://jalt-publications.org/archive/proceedings/2006/E038.pdf

Nation, I. S. P., \& Waring, R. (2019). Teaching extensive reading in another language. New York, NY: Routledge.

Renandya, W. A., Krashen, S., \& Jacobs, G. M. (2018). The potential of series books: How narrow reading leads to advanced L2 proficiency. LEARN Journal: Language Education and Acquisition Research Network, 11(2), 148-154. Retrieved from https://so04.tci-thaijo.org/index.php/LEARN/ article/view/161631/116569

Shelton-Strong, S. J. (2012). Literature circles in ELT. ELT Journal, 66(2), 214-223. https://doi. org/10.1093/elt/ccr049

\section{Appendix A}

\section{Mid-Term Survey}

Sherlock Holmes and the Duke's Son

Survey / Self Reflection

1. How much of the story did you understand?

\begin{tabular}{|c|c|c|c|c|}
\hline 1 & 2 & 3 & 4 & 5 \\
$\begin{array}{c}\text { Understood } \\
\text { none of it }\end{array}$ & $\begin{array}{c}\text { Understood } \\
\text { hardly any of it }\end{array}$ & $\begin{array}{c}\text { Understood } \\
\text { some of it }\end{array}$ & $\begin{array}{c}\text { Understood } \\
\text { most of it }\end{array}$ & $\begin{array}{c}\text { Understood } \\
\text { everything }\end{array}$ \\
\hline
\end{tabular}

2. How interesting was the story?

\begin{tabular}{|c|c|c|c|c|}
\hline 1 & 2 & 3 & 4 & 5 \\
Very boring & Boring & It was OK & Interesting & Very interesting \\
\hline
\end{tabular}

3. Which roles did you try? (circle)

Discussion Leader Summarizer Connector Word Master Passage Person

a. Which role was the most difficult?

b. Which role was the easiest?

b. Which role was the most interesting?

4. How good were your contributions to the discussion?

\begin{tabular}{|c|c|c|c|c|}
\hline 1 & 2 & 3 & 4 & 5 \\
Very bad & Quite bad & OK & Quite good & Very good \\
\hline
\end{tabular}

5. What can you do to understand the story / join in the discussion more?

6. What can your teacher do to help you understand the story / join in the discussion more? 


\section{Appendix B}

End-of-Term Survey

Sherlock Holmes and the Sport of Kings

Survey / Self Reflection

1. How much of the story did you understand?

\begin{tabular}{|c|c|c|c|c|}
\hline 1 & 2 & 3 & 4 & 5 \\
$\begin{array}{c}\text { Understood } \\
\text { none of it }\end{array}$ & $\begin{array}{c}\text { Understood } \\
\text { hardly any of it }\end{array}$ & $\begin{array}{c}\text { Understood } \\
\text { some of it }\end{array}$ & $\begin{array}{c}\text { Understood } \\
\text { most of it }\end{array}$ & $\begin{array}{c}\text { Understood } \\
\text { everything }\end{array}$ \\
\hline
\end{tabular}

2. How interesting was the story?

\begin{tabular}{|c|c|c|c|c|}
\hline 1 & 2 & 3 & 4 & 5 \\
Very boring & Boring & It was OK & Interesting & Very interesting \\
\hline
\end{tabular}

3. Which roles did you try? (circle)

Discussion Leader Summarizer Connector Word Master Passage Person

a. Which role was the most difficult?

b. Which role was the easiest?

b. Which role was the most interesting?

4. How good were your contributions to the discussion?

\begin{tabular}{|c|c|c|c|c|}
\hline 1 & 2 & 3 & 4 & 5 \\
Very bad & Quite bad & OK & Quite good & Very good \\
\hline
\end{tabular}

5. Which story was the most interesting? The Duke's Son / The Sport of Kings

Why?

6. Which story was the easiest to understand? The Duke's Son / The Sport of Kings Why?

7. How interested are you in reading more Sherlock Holmes books in English? Why?

\begin{tabular}{|c|c|c|c|c|}
\hline 1 & 2 & 3 & 4 & 5 \\
Not at all & Not really & A little & Interested & Very interested \\
\hline
\end{tabular}

8. How interested are you in reading other English books? Why?

\begin{tabular}{|c|c|c|c|c|}
\hline 1 & 2 & 3 & 4 & 5 \\
Not at all & Not really & A little & Interested & Very interested \\
\hline
\end{tabular}

